\title{
Mechanical properties under quasi-static loading of the core made of flax/poly(lactic acid) composite
}

\author{
M.Y.M. Zuhri 1), 2), *) (oRCID ID: 0000-0002-1069-7345), M.A. Nasrudin ${ }^{1)}$, M.A.M. Nasrodin ${ }^{1)}$, \\ S.M. Sapuan ${ }^{1), 2)}$ (0000-0003-0627-7951), M.Z. Hassan ${ }^{3)}$ (0000-0002-2321-0604), \\ DOI: dx.doi.org/10.14314/polimery.2021.3.5
}

\begin{abstract}
This paper investigates the mechanical behavior of an interlocking structure made of flax/poly(lactic acid) (PLA) composites manufactured using hot press compression molding. The flax/PLA composite manufactured at a temperature of $190^{\circ} \mathrm{C}$ and pressed for 10 minutes obtained the highest values of strength and modulus. A range of core cell sizes between 10 and $40 \mathrm{~mm}$ with a height from 20 to $40 \mathrm{~mm}$ was fabricated using a simple slotting technique. The larger core size offers a better relative density value when comparing to the smaller size (with a similar number of layers). The results also showed that the $10 \mathrm{~mm}$ core size exhibits better compression strength than the 20 and $40 \mathrm{~mm}$ core sizes. In contrast, the specific energy absorption (SEA) values of the structures increase as the core size decreases.
\end{abstract}

Keywords: compression strength, flax, interlocking, specific energy absorption.

\section{Właściwości mechaniczne pod obciążeniem quasi-statycznym rdzenia wykonanego z kompozytu len/poli(kwas mlekowy)}

\begin{abstract}
Streszczenie: Zbadano właściwości mechaniczne struktury zazębiającej się, wytworzonej z kompozytu len/poli(kwas mlekowy) (PLA) metodą prasowania na gorąco. Struktura z kompozytu prasowanego przez 10 minut $\mathrm{w}$ temperaturze $190^{\circ} \mathrm{C}$ wykazywała największe wartości wytrzymałości na ściskanie i modułu. Za pomocą prostej techniki szczelinowania wytworzono szereg komórek rdzeniowych o wymiarze podstawy od 10 do $40 \mathrm{~mm}$ i wysokości od 20 do $40 \mathrm{~mm}$. Większy wymiar podstawy rdzenia zapewniał korzystniejszą wartość gęstości względnej. Stwierdzono, że struktury o wymiarze podstawy rdzenia $10 \mathrm{~mm}$ wykazują lepszą wytrzymałość na ściskanie niż struktury o wymiarach 20 i $40 \mathrm{~mm}$, natomiast wartości absorpcji energii właściwej (SEA) struktur rosną wraz ze zmniejszaniem się wymiarów podstawy rdzenia.
\end{abstract}

Słowa kluczowe: wytrzymałość na ściskanie, len, zazębianie, energia właściwa.

Sandwich structures made of advanced composite materials are progressively replacing the common materials such as aluminum and steel in various industries such as aircraft, automobile and marine ship [1]. This so-called lightweight structures offer many advantages including good stiffness to weight ratio, good thermal and acoustic isolation properties as well as steadiness under compressive loadings [2,3]. Several studies have been carried out

\footnotetext{
1) Advanced Engineering Materials and Composites Research Centre, Department of Mechanical and Manufacturing Engineering, Universiti Putra Malaysia, 43400 UPM Serdang, Selangor, Malaysia

2) Laboratory of Biocomposite Technology, Institute of Tropical Forestry and Forest Products (INTROP) Universiti Putra Malaysia, 43400 UPM Serdang, Selangor, Malaysia.

3) Razak Faculty of Technology and Informatics, Universiti Teknologi Malaysia, 54100 Kuala Lumpur, Malaysia

*) Author for correspondence: zuhri@upm.edu.my
}

to design a lightweight structure using various materials with different shape. For example, Xiong et al. [4] developed carbon fiber composite pyramidal truss cores using the molding hot-press technique. Following this, they extended their study on the bending behavior of egg honeycomb and pyramidal honeycomb cores made of carbon fiber composites [5]. Jiang et al. [6] found that an interlocking orthogrid of carbon fiber reinforced plastic (CFRP) offers greater strength and better weight efficiency compared to the 3D lattice truss composites. Li et al. [7] analyzed the bending behavior of the wood-based structural panel using a simplified analytical model. Gautam et al. [8] studied the strut reinforced kagome structure of acrylonitrile butadiene styrene (ABS) fabricated by using fused deposition modelling (FDM).

Recently, there is some interest to replace synthetic fibers with more environmental-friendly materials [9]. A study on the honeycomb core of jute reinforced vinylester composites revealed that this natural-based mate- 
rial has potential as a replacement to those standard cores [10]. Rao et al. [11] investigated the compression and flexural capabilities of honeycomb cores made of sisalpolypropylene (PP) composites. The authors found that the specific strength of the sisal-PP honeycomb cores is almost twice higher than that offered by the pure PP honeycomb cores. Jusoh et al. [12] reviewed the natural fiber composites as potentially used for corrugated core structures. Du et al. [13] stated that skins made of biofiber based paper-reinforced polymer showed comparable flexural properties to the glass fiber reinforced polyurethane skins. An investigation on the mold design and manufacturing considerations of honeycomb made of kenaf/epoxy composite has been carried out by Manan et al. [14]. Selmi et al. [15] using acoustic emission conducted the compression damage analysis of natural flax fiber honeycomb with three different densities: $100 \mathrm{~g} / \mathrm{m}^{2}$, $150 \mathrm{~g} / \mathrm{m}^{2}$ and $200 \mathrm{~g} / \mathrm{m}^{2}$. Based on the previous works, it is noted that the natural fiber-based composite has great potential to be used in sandwich core structure, especially for low-end engineering applications such as packaging and interior parts. From the literatures, it is found that very limited study has been conducted on the capability of using natural fiber as core material. Therefore, the objective of this study is to investigate the compression behavior of environmentally friendly interlocking structures made of flax reinforced polylactide composite. The fabrication process, testing and the effects of cell size on the compression properties are discussed.

a)

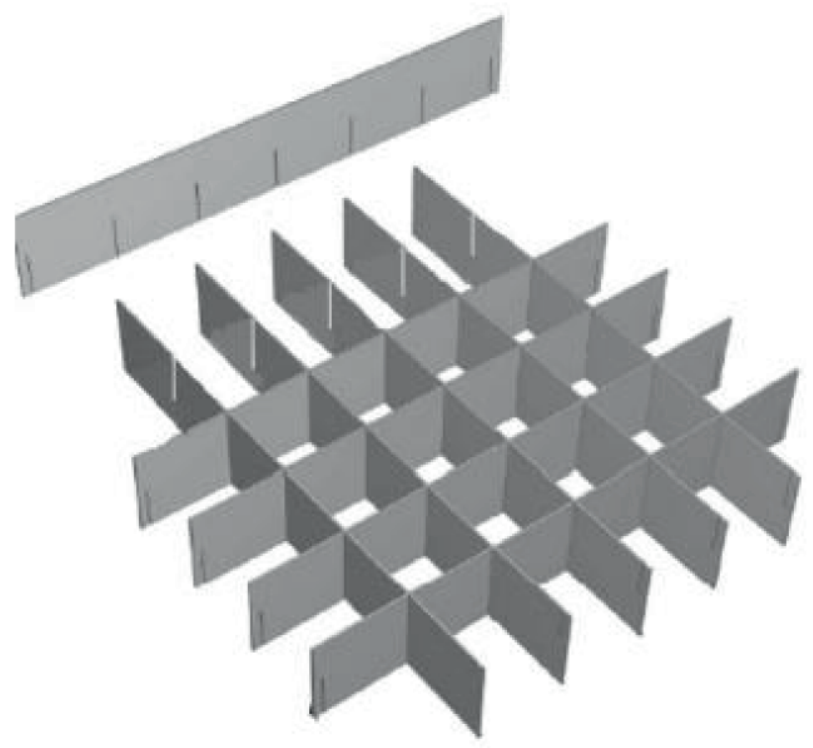

\section{EXPERIMENTAL PART}

\section{Materials}

In this study, the test specimens for experimental investigations are made of pre-preg of Biotex flax fiber reinforced reinforced poly(lactic acid) (also known as polylactide) thermoplastic (flax/PLA) thermoplastic (flax/PLA) in the form of $2 \times 2$ twill with a weight of $400 \mathrm{~g} / \mathrm{m}^{2}$. The woven fabric consists of $40 \%$ fiber. The materials were supplied by EasyComposites, UK.

\section{Fabrication of composite panel}

A hot compression molding method was used to manufacture the flax/PLA composite panels with a dimension size of $300 \times 300 \times 1.5\left(\mathrm{~mm}^{3}\right)$. Three layers of prepreg flax/PLA were used to form the composite panel. Here, the manufacturing parameters were set to temperatures ranging from $170^{\circ} \mathrm{C}$ to $190^{\circ} \mathrm{C}$, under a pressing time of 10 to 20 minutes with the pressure fixed to $0.2 \mathrm{MPa}$. The materials were arranged in a $0 \% 90^{\circ}$ fiber orientation.

\section{Fabrication of sandwich structure}

Fabrication of the interlocking cores starts with cutting the composite panel using a bench saw machine to turn it into a composite strip. Then, a simple slotting technique is used to interlock the composite strips with an interference fit. This method also has been used by Jiang et al. [6] and Roslan et al. [16]. In this study, the investigations on the flax/PLA cores are set to 4 unit cells with square shape. Similar composite materials are also used as their skins, which are bonded to the core using an epoxy resin.

b)

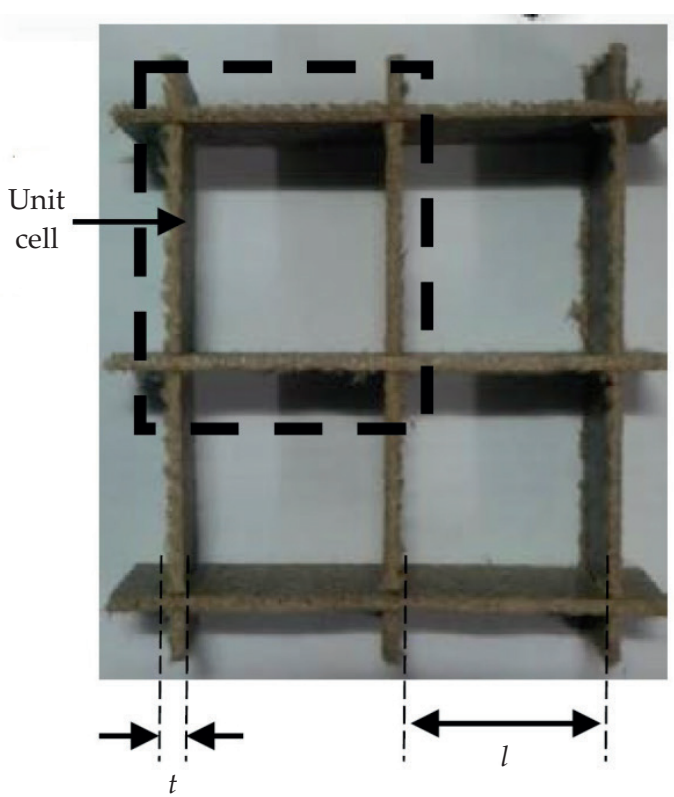

Fig. 1. The fabrication of flax/PLA interlocking structure: a) schematic diagram of slotting technique [17], b) plan view of square interlocking 
$\mathrm{T}$ a b 1 e 1. Tensile properties of flax/PLA composite panels

\begin{tabular}{c|c|c|c}
\hline Temperature, $^{\circ} \mathrm{C}$ & Pressing time, min & Tensile strength, MPa & Tensile modulus, GPa \\
\hline \multirow{2}{*}{170} & 10 & $17.9 \pm 3.4$ & 4.12 \\
& 15 & $16.0 \pm 2.4$ & 4.60 \\
& 20 & $18.3 \pm 2.6$ & 4.85 \\
\hline \multirow{2}{*}{180} & 10 & $12.7 \pm 3.5$ & 3.06 \\
& 15 & $12.6 \pm 1.7$ & 3.63 \\
\hline \multirow{2}{*}{190} & 20 & $14.2 \pm 1.6$ & 4.80 \\
& 10 & $23.2 \pm 2.7$ & 5.15 \\
& 15 & $11.1 \pm 2.0$ & 3.78 \\
\end{tabular}

Figure 1 shows the slotting technique and the flax/PLA interlocking core structure [17].

\section{Methods of testing}

An initial study is carried out on the effect of the manufacturing process through tensile testing following the ASTM D3039. Following this, the higher tensile strength value is taken as the manufacturing process for the fabrication of core and skins of the sandwich structure. Later, the out-of-plane compression testing for the sandwich structure is conducted following the ASTM C365 standard. Both tests are conducted using the available machine which is Instron 8500 with $100 \mathrm{kN}$ load cell at a crosshead displacement of $2 \mathrm{~mm} / \mathrm{min}$. Three samples are tested for each parameter. Here, the capability of interlocking structures under compression loading are investigated in terms of their compression strength and energy-absorbing ability. The interlocking structures are compared through their relative density, which is calculated baseing on Equation (1).

$$
\bar{\varrho}=\frac{2 t}{l}
$$

where $t$ is the cell wall thickness and $l$ is the core cell size.

\section{RESULTS AND DISCUSSION}

\section{Tensile properties of flax/PLA composite}

At first, the effect of temperature and pressing time on the tensile strength of the flax/PLA composites were investigated. The flax/PLA composites with an orientation of $0^{\circ} / 90^{\circ}$ were tested until they failed. Table 1 tabulates the tensile properties of the tested flax/PLA composite panels.

It is seen that the composite manufactured at a temperature of $190^{\circ} \mathrm{C}$ showed the highest values of tensile strength and modulus, which lie at $23.2 \mathrm{MPa}$ and $5.15 \mathrm{GPa}$, respectively. Besides, more than $50 \%$ of the differences of tensile properties were observed between the composite panels pressed under 10 and 20 minutes (at the temperature of $190^{\circ} \mathrm{C}$ ). Here, by giving a longer pressing time, the strength of the composite is reduced. This is due to the fact that matrix covering the fiber has degraded and reduced its ability to strengthen the fiber. Similar results can be seen in the work conducted by Tharazi et al. [18]. They found that tensile strength is highly influenced by the interaction effect of temperature and pressure, temperature, and heating time. In addition, Pickering et al. [19] suggested that viscosity of the matrix need to be controlled carefully during the pressing and heating process, especially for thick samples. This is to ensure that the matrix is impregnating the gap between the fibers completely. On the other hand, the investigations realized both at $170^{\circ} \mathrm{C}$ and $180^{\circ} \mathrm{C}$ showed no significant differences either on the strength or modulus values. Surprisingly, the flax/PLA composite for $180^{\circ} \mathrm{C}$ gives lower values than those offered by $170^{\circ} \mathrm{C}$. This could be due to the fact that the polymer matrix was not completely melted at the given manufacturing process at temperature of $170^{\circ} \mathrm{C}$. Close observation on the failure of the tensile testing of the flax/PLA composites are mostly exhibiting fiber breakage across the width of the sample.

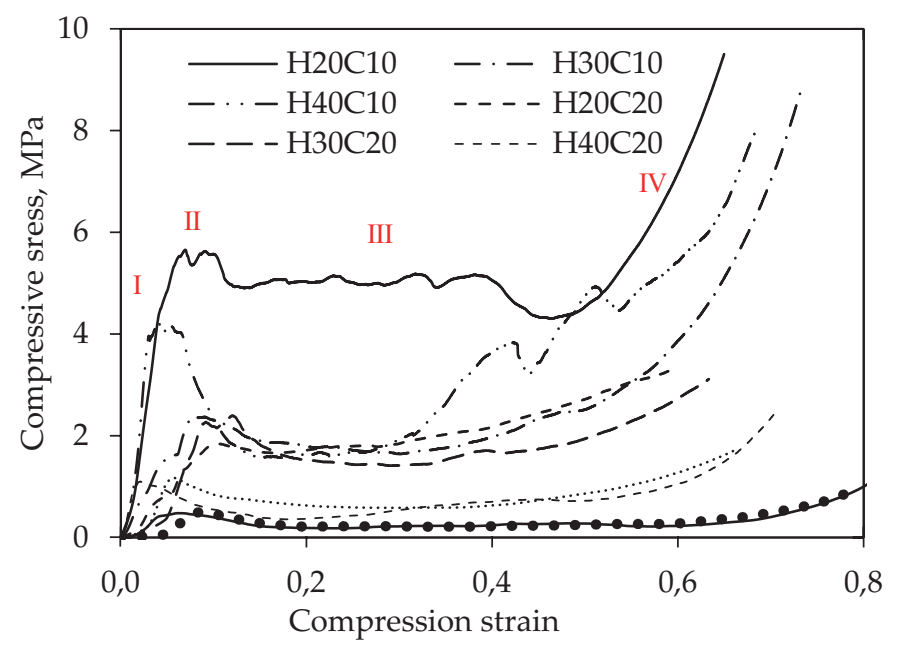

Fig. 2. Typical stress-strain curves of the flax/PLA interlocking structures 


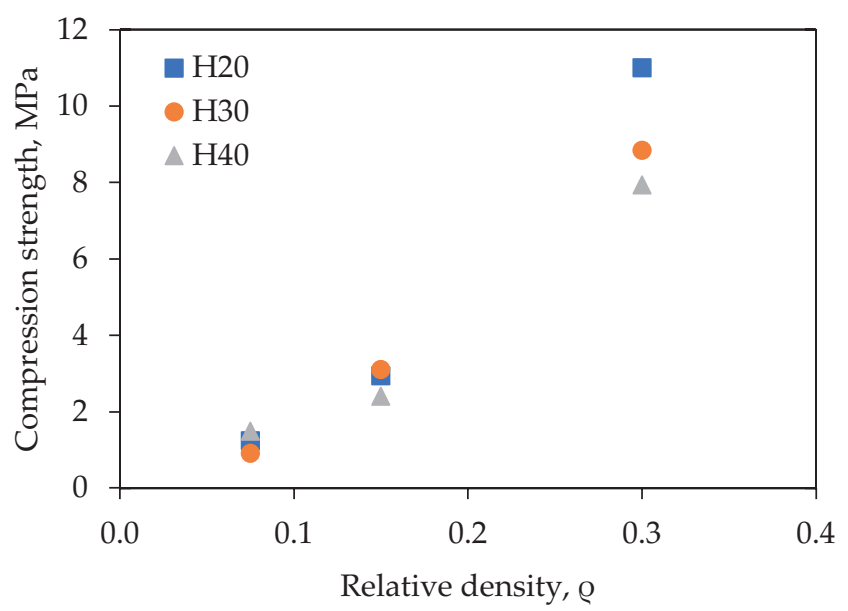

Fig. 3. Compression strength of the flax/PLA interlocking structures

\section{Compression properties of flax/PLA interlocking structures}

Following the investigation on the tensile properties of the flax/PLA composite, the temperature of $190^{\circ} \mathrm{C}$ with a pressing time of 10 minutes has been selected to be used for fabricating the interlocking structures. Here, the interlocking structures were tested under quasi-static loading conditions, aligned to the fiber direction. The cores were fixed at 4 unit cells with a difference of cell size (10, 20 and $40 \mathrm{~mm})$ and height $(20,30$ and $40 \mathrm{~mm})$. The cell size effect was compared baseing on their relative density. Figure 2 shows the stress-strain relationship of the flax/PLA interlocking structures under different cell sizes and heights. The samples were coded in terms of their height $(\mathrm{H})$ and core size $(\mathrm{C})$, i.e., $\mathrm{H} 20 \mathrm{C} 10$ represents the core height of $20 \mathrm{~mm}$ with a cell size of $10 \mathrm{~mm}$. Here, the calculated relative densities of the core structures are $0.075,0.15,0.3$, which represent cell sizes of 40,20 and $10 \mathrm{~mm}$, respectively.

In Fig. 2, the flax/PLA cores are experiencing an elastic property (stage I) until reaching their maximum strength (stage II). As the loading continues, the strength of the core decreases with a gradual transition and occurres a stress plateau at stage III. This is similar to the results obtained by Stocchi et al. [10]. At stage IV, the cores are completely crushed and there is no further resistance to load. All configurations are showing a similar trend of stress-strain curves. Figure 3 shows the compression testing results of the flax/PLA interlocking structures. The compression properties were compared based on their core relative density.

Clearly, the larger cell size is more lightweight than the smaller size with the same layering number regardless their height. Indeed, the smaller cell size $(10 \mathrm{~mm})$ offers the highest compression strength, nearly ten times higher than the $40 \mathrm{~mm}$ cell size at lower height. This suggests that a small core at lower height has more capability to

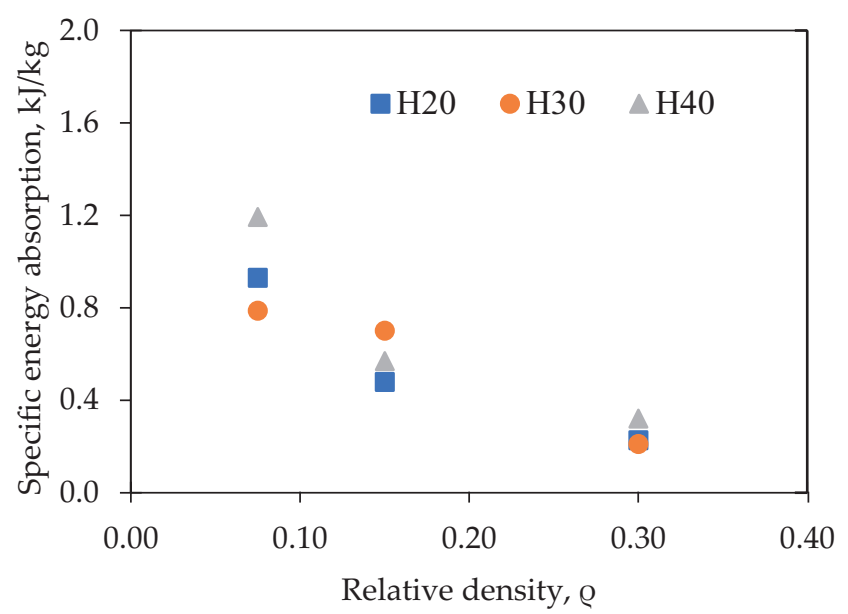

Fig. 4. Specific energy absorption for different core size and height

withstand loading under compression. In addition, the surface contact area of the core with a smaller size will give a greater bonding area [16].

One of the key properties of the sandwich structure is its capability to absorb energy. In this study, the energy absorption capability was determined from the energy under the load-displacement trace until the onset of densification and divided by the mass of the core sample. Figure 4 presents the specific energy absorption (SEA) of the flax/PLA cores with different core size and height. In the figure, it is shown that as the relative density of the core structure increases, their SEA values will be decreased. Closer examination indicated that the core of $10 \mathrm{~mm}$ cell size has much lower SEA value (by more than $50 \%$ ) than that offered by the core with $40 \mathrm{~mm}$. The flax/PLA core structures are found to fail in the form of fiber breakage, localized buckling and buckling-to-delamination (which is visible within the vertical web).

\section{CONCLUSION}

An investigation on the potential of using flax reinforced polylactide composite in sandwich structure has been carried out. The flax/PLA composites manufactured at a temperature of $190^{\circ} \mathrm{C}$ and pressed under 10 minutes offer the highest tensile properties value. The results for the tensile strength and modulus are $23.2 \mathrm{MPa}$ and $5.15 \mathrm{GPa}$, respectively. Following this, a range of interlocking core size from 10 to $40 \mathrm{~mm}$ and height from 20 to $40 \mathrm{~mm}$ was fabricated and tested with a similar number of layers. The results showed that the $10 \mathrm{~mm}$ core size exhibits better compression strength than the 20 and $40 \mathrm{~mm}$ core sizes, at a core height of $20 \mathrm{~mm}$ with a value of $11 \mathrm{MPa}$. In contrast, the $40 \mathrm{~mm}$ core size with $40 \mathrm{~mm}$ height offers better energy absorption capability. It is also seen that as the interlocking core size is increasing, the value of $S E A$ is decreasing. The energy-absorbing capability of the larger core size with greater height has out- 
performed the smaller core size. Most of the cores failed in fiber breakage, localized buckling and buckling-todelamination within the vertical web.

\section{ACKNOWLEDGMENT}

This work is supported by Universiti Putra Malaysia through the Putra Grant (GP-IPM/2016/9499400). The assistance from Mr. Muhammad Wildan Ilyas Mohamed Ghazali and Mr. Mohd Saiful Azuar Md. Isa are much appreciated.

\section{REFERENCES}

[1] Belouettar S., Abbadi A., Azari Z. et al.: Composite Structures 2009, 87 (3), 265. https://doi.org/10.1016/j.compstruct.2008.01.015

[2] Konka H.P., Wahab M.A., Lian K.: Journal of Engineering Materials and Technology 2012, 134 (1), 011010. https://doi.org/10.1115/1.4005349

[3] Manalo A., Aravinthan T., Fam A. et al.: Journal of Composites for Construction 2016, 21, 04016068. http://dx.doi.org/10.1061/(ASCE)CC.1943-5614.0000729

[4] Xiong J., Ma L., Wu L. et al.: Composite Structures 2010, 92, 2695. https://doi.org/10.1016/j.compstruct.2010.03.010

[5] Xiong J., Ma L., Stocchi A. et al.: Composite Structure 2014, 108, 234. https://doi.org/10.1016/j.compstruct.2013.09.035

[6] Jiang S., Sun F., Zhang X., Fan H.: Composite Structures 2017, 176, 55. https://doi.org/10.1016/j.compstruct.2017.05.029

[7] Li J., Hunt J.F., Gong S., Cai Z.: Composite Structures 2016, 136, 16. https://doi.org/10.1016/j.compstruct.2015.09.045

[8] Gautam R., Idapalapati S., Koh E.S.L.: “Compressive behavior of strut reinforced Kagome structures fabricated by fused deposition modeling", Materials from $3^{\text {rd }}$ International Conference on Progress in Additive
Manufacturing (Pro-AM 2018), Nanyang Executive Centre, NTU, Singapore, 14-17 May 2018, p. 220.

[9] Vitale J.P., Francucci G., Xiong J., Stocchi A.: Composites Part A: Applied Science and Manufacturing 2017, 94, 217. https://doi.org/10.1016/j.compositesa.2016.12.021

[10] Stocchi A., Colabella L., Cisilino A., Álvarez V.: Materials and Design 2014, 55, 394. https://doi.org/10.1016/j.matdes.2013.09.054

[11] Rao S., Jayaraman K., Bhattacharyya D.: Composites Part A: Applied Science and Manufacturing 2011, 42, 1236. https://doi.org/10.1016/j.compositesa.2011.05.006

[12] Jusoh A., Rejab M.R.M., Siregar J.P., Bachtiar D.: MATEC Web of Conferences 2016, 74, 00033. http://dx.doi.org/10.1051/matecconf/20167400033

[13] Du B., Chen L.M., Zhou H. et al.: International Journal of Applied Mechanics 2017, 9 (8), 1750110. https://doi.org/10.1142/S1758825117501101

[14] Manan N.H., Majid D.L., Romli F.I.: IOP Conf. Series: Materials Science and Engineering 2016, 152, 012013. https://doi.org/10.1088/1757-899X/152/1/012013

[15] Selmi S., Habibi M., Laperrière L., Kelouwani S.: Journal of Natural Fibers 2020, 1. https://doi.org/10.1080/15440478.2020.1789531

[16] Roslan S.A.H, Hassan M.Z., Rasid Z.A. et al.: International Journal of Automotive and Mechanical Engineering 2015, 12, 2882. http://dx.doi.org/10.15282/ijame.12.2015.7.0242

[17] Côté F., Russell B.P., Deshpande V.S., Fleck N.A.: Journal of Applied Mechanics 2009, 061004-1.

[18] Tharazi I., Sulong A.B., Muhamad N. et al.: Procedia Engineering 2017, 184, 478. https://doi.org/10.1016/j.proeng.2017.04.150

[19] Pickering K.L., Aruan Effendy M.G., Le T.M.: Composites Part A: Applied Science and Manufacturing 2016, 83, 98. https://doi.org/10.1016/j.compositesa.2015.08.038

Received 6 V 2020.

\section{Rapid Communications}

Przypominamy Autorom, że publikujemy artykuły typu Rapid Communications - prace oryginalne wyłącznie w języku angielskim (o objętości 4-5 stron maszynopisu z podwójną interlinią, zawierające 2-3 rysunki lub 1-2 tabele), którym umożliwiamy szybką ścieżkę druku (do 3 miesięcy od chwili ich otrzymania przez Redakcję). Artykuł należy przygotować wg wymagań redakcyjnych zamieszczonych we wskazówkach dla P.T. Autorów.

We remind Authors that we publish articles of the Rapid Communications type - the original papers, in English only (with a volume of 4-5 pages of double-spaced typescript, containing 2-3 figures or 1-2 tables), which allow a fast print path (up to 3 months from when they are received by the Editorial Board). The article should be prepared according to the editorial requirements included in the Guide for Authors. 